\title{
Paideusis
}

\section{Mens Sana, Sano in Corpore: Meeting Sheryle at the Gym}

\section{Michael J. B. Jackson}

Volume 13, Number 1, 2000

URI: https://id.erudit.org/iderudit/1073023ar

DOI: https://doi.org/10.7202/1073023ar

See table of contents

Publisher(s)

Canadian Philosophy of Education Society

ISSN

0838-4517 (print)

1916-0348 (digital)

Explore this journal

Cite this document

Jackson, M. (2000). Mens Sana, Sano in Corpore: Meeting Sheryle at the Gym. Paideusis, 13(1), 61-63. https://doi.org/10.7202/1073023ar

This document is protected by copyright law. Use of the services of Erudit (including reproduction) is subject to its terms and conditions, which can be viewed online.

https://apropos.erudit.org/en/users/policy-on-use/ 


\section{MENS SANA, SANO IN CORPORE: \\ Meeting Sheryle at the Gym ${ }^{1}$}

\section{Michael J. B. Jackson}

Surprisingly, since retiring, I have taken to going to the gym. Not immediately, admittedly; it took some time. But I felt there had long been something lacking in my life, probably due to my school's shockingly bad physical education programme, if we could even call it that (and for which my parents paid good money). I felt I had not become a well rounded person despite the school's repeated emphasis on just this goal.

I had done tolerably but not exceptionally well on the academic side and not much at all in other areas like the arts and physical education. Yet the school paid regular tribute to all-round development--at times, I thought, to the detriment of academic study, lauding born actors and natural athletes (even as it left the rest of us to run around the gym or go out and play organized "games"). It had no objection to students being bright and moderately inquiring or doing well in their studies; it just didn't make much of those things most of the time. It required music, gym or occasionally a swim, and participation in a sport each term; actually, my university required men to practice "a sport" until numbers became unmanageable. But coaching was reserved for the "first team" or the Little Theatre. So the rest of us never really learned to exercise our powers, to know what we could do, or the pleasure of being fit--to know ourselves. No one thought to show us or provided the occasion. But the school, I think, was right in the object of its lip service, even if the ways it set about achieving its goals were doubtful.

As Bergmann Drewe says, it is always wise if one can to defend education for its intrinsic value despite any personal, economic, or social instrumental value it may have. But to do so by tying education exclusively to the mind is to allow the opponents of anything but a strictly academic curriculum to impose their own narrow if important criteria of success--and it is never a good idea to have your opponents define success. And oddly, it now seems to me, this is just where physical education has an advantage, for physical activity is itself part of a well-rounded life, not (whatever impression Peters may give from time to time) an isolated set of skills, merely a pastime, or playing games. And so its value is not instrumental any more than enjoying a good book, attending a play or a concert, or participating in a conversation is (only) about "learning something" from the experience. It is itself an enriching, worthwhile experience, part of a full life, not merely a means to 
health, longevity, beauty, or pleasure. The enjoyment, Aristotle might have noted, is in the activity itself, in the exercise of one's powers. In this it seems to have an advantage not shared by much of what we learn in school, notably the academic stuff we swot up for exams where much of the information and many of the skills are of little inherent interest, important though they may be for marks or mastering something else. Oddly--though perhaps not to many bored students--the academic curriculum, the one supposedly developing the mind, is the one whose value, if it has one, typically seems only instrumental.

Thus I read Bergmann Drewe's article with a new interest and sympathy, and I was disappointed to find I disagreed for two reasons. First, education is not essentially about rationality but about well rounded people. It is about developing many human potentials--not all of them, to be sure, but those that enable people to choose and live rich, full lives. This means knowing ourselves. Physical education enables us to develop and learn about our powers as we practice them just as much as do intellectual and aesthetic education.

Second, her rationale remains instrumental and so subject to her initial objections. Despite her much needed observations about competition (and when more than while economic competition is the prevailing value), physical education becomes a means to moral education and to making practical inferences (pp. 39-40). But even if individual study is productive in many areas of the curriculum, we might find that cooperative education outside the physical education class contributes to these ends just as well or better, with no reason remaining to prefer or retain physical education.

Of course, Bergmann Drewe begins with the challenge not to defend physical education per se but to defend its place in the school curriculum (pp. 33, 42). That it is an integral part of a well rounded life, needs to be taught, and needs to be considered alongside other educational activities (intellectual and aesthetic, for example) which find their place in school make the school a natural home for it: the end of schooling is surely not to prepare for more schooling (to get the grades needed to get into university) but to know oneself and be able to choose and live a worthwhile life. Bergmann Drewe rightly notes links with "education about movement" and "education through movement" (p. 41). But she slips from the recognition that to question the aims of education (or any activity) is to make a commitment to rationality to the belief that therefore the aim of education (or any activity?) itself is rationality (p. 34) and so to a narrow conception of education that defeats her own end. 


\section{Notes}

1. Juvenalis, Satire x. 346, in Craufurd Tait Ramage, Beautiful Thoughts from Latin Authors, Liverpool: Edward Howell, 1869, 255, ". . Orandum est: ut sit mens sana in corpore sano"; ". . . be this thy prayer: Vouchsafe me health of body and peace of mind".

Bergmann Drewe, Sheryle. "Acquiring Practical Knowledge: A Justification for Physical Education", Paideusis 12: 2, 1999, 33-44. 